\title{
Health Sector Collective Bargaining and the Employment Contracts Act: A Case Study of Nurses
}

\section{Sarah Oxenbridge*}

This case study describes and analyses the negotiation of a collective employment contract between an area health board management and regional representatives of the New Zealand Nurses Association during the first set of negotiations conducted under the Employment Contracts Act 1991. The study found that, contrary to claims by the Act's proponents, the Act does not lead to improved co-operation and communication between employers and employees. However, a high level of communication and co-operation was evident in the employee-union relationship, and it was found that certain provisions of the Employment Contracts Act afford employees greater power to determine their conditions of employment.

\section{Introduction}

The central aim of the Employment Contracts Act 1991 is, in the words of its long title, "to promote an efficient labour market" (ECA, 1991). Additional stated aims of the Act are premised on three key themes: freedom of association, freedom of representation and freedom of contract. These explicit objectives are accompanied by implicit aims. On the introduction of the Act, unionists accused the legislation's architects of having a hidden agenda - the lowering of wages, particularly penal rates, and the exclusion of unions from the employment relationship. Meanwhile, the Act's supporters stressed the opportunities for individualism, communication and co-operation that the legislation promoted, and emphasised the newfound freedom for individual workers to determine their employment conditions. Member of Parliament and Chair of the Labour Select Committee Max Bradford (1991: 17) stated that the Act had resulted in "unlimited opportunity for employers and employees to shape arrangements in their own workplaces". The Act's leading proponent, the Minister of Labour Bill Birch, stated that the new legislation "signals a move from the old conflict industrial relations model to a new, co-operative relationship between employers and employees" (Birch, 1991: 7). Similarly, Brook (1991: 8) contrasted New Zealand's previous industrial relations system "based on a view of employment relationships

* Industrial Relations Centre, Victoria University of Wellington. This research was undertaken while the author was a Masters student at Canterbury University. The author would like to thank the organisers and delegates of the Canterbury branch of the New Zealand Nurses Association and Ian Whitelaw, Industrial Relations Manager, Canterbury Area Health Board for their time and co-operation. The author also gratefully acknowledges the assistance of Pat Walsh and Rose Ryan, who patiently reviewed earlier drafts of this paper, and the anonymous Journal referees for their helpful comments. 
as inherently adversarial or exploitative" with the new system in which "employment relationships are a matter of mutual benefit to employers and workers, and for this reason are fundamentally co-operative". However, the Act's critics maintain that this conception of the employment relationship is deficient, as it ignores the imbalance in power between the parties to a contract (Douglas, 1991; Harbridge, 1993; Scott, 1991). According to the rhetoric surrounding the Act's introduction, the main aim of the legislation is to encourage mutual co-operation between employers and employees, resulting in greater employee input in the negotiation process and power to determine wages and conditions. However, opponents argue that the Act promotes employment relationships where the opposite is the reality, as it tilts the balance of power in favour of employers and provides them with new freedoms to reduce wages and conditions of employment.

Less than six months after its introduction, the Employers Federation's labour market manager claimed that "improved workplace communication and flexibility had been the Act's most notable success" as "staff and management were now able to talk to each other in ways not possible under a confrontational system" (Christchurch Press, 17/12/91: 3). Similarly, the Federation's chief executive stated that the move to a contract-based system of labour relations was accelerating with "markedly less conflict than detractors had predicted" (Marshall, 1992). However, three years on from its introduction, conflicting views exist as to the extent of the Act's success in promoting closer workplace relationships between employers and employees. As Hughes (1992) notes, the frequent reporting of lockouts does little to support claims by the government and pressure groups that the Employment Contracts Act is about co-operation rather than confrontation. Similarly, the Department of Labour's recent survey of labour market adjustment under the ECA found that many employees were uncomfortable with the new environment (Department of Labour, 1993). The survey reported that employees' views on the extent of improvements in staff/management co-operation and communication and employee trust of management were significantly different and less favourable than employers'. Among public sector employees for example, $45 \%$ felt that employee trust of management had decreased over the last year, while $27 \%$ believed that co-operation between management and employees had decreased. In addition, case studies and reports of labour relations in the post-ECA environment in the retail industry (Hammond, 1993; National Distribution Union, 1992), the private and public health sectors (Hill and Du Plessis, 1993; New Zealand Nurses Organisation, 1993), and a number of service industries (Gosche, 1992), have highlighted the tendency for employers to unilaterally determine wages and conditions without entering into bargaining with employees or their representatives. Moreover, a number of these studies draw attention to increasing levels of worker exploitation and of conflict between employees and employers.

The purpose of the present study is to examine the process of collective bargaining in light of the predictions of the Act's supporters and opponents. A series of propositions based on these predictions were developed and tested in the context of collective employment contract negotiations between Canterbury Area Health Board (CAHB) management and New Zealand Nurses Association (NZNA) regional organisers and delegates which took place between May and November 1992. The case study inethod of research was used in which data from personal interviews, observation of the negotiation process and documentary sources was collected and analysed through content analysis. Semi-structured interviews were conducted with NZNA regional organisers and the CAHB's industrial 
relations manager prior to and following the negotiation period. Eight of the ten days of contract negotiations were observed, as were two stopwork meetings where both parties addressed nursing staff. During adjournments, observation of the NZNA team took place in order to record interactions between team members. In addition, a number of documentary sources were examined. These inclucied newspaper and magazine articles, information bulletins distributed to members by the NZNA Canterbury branch and union central office, and miscellaneous documents such as CAHB memoranda to employees and memoranda between the negotiating parties.

Prior to setting out results, the paper will provide a brief overview of the research propositions and the context within which the negotiations took place. The research findings are presented in two parts; the first is a descriptive summary of the negotiation process, the second involves an analysis of the negotiation or bargaining processes in light of the research propositions.

\section{Research propositions}

Four research propositions were developed in order to test certain predictions regarding the outcomes of the new legislation in the context of a set of collective employment contract negotiations. These are: first, that the ECA will lead to significant changes in the bargaining process; second, that employers will use the Act to achieve the "implicit" aims identified by its critics; third, that the Act will not provide employees with greater power to determine their own employment conditions; and finally, that the Act will not lead to improved co-operation and communication between employers and employees.

In the period leading up to the Act's passage, it became evident that the only prediction that was consistently made by both critics and supporters of the new legislation was that the process of negotiating wages and conditions would change markedly. Consequently, the first proposition tests whether the collective bargaining process has changed, and if so, for what reasons. The second proposition posits that employers will use the legislation primarily to achieve the Act's "implicit aims", particularly the reduction of wages and conditions and the exclusion of unions from the employment relationship. The third proposition predicts that due to the inherent power imbalance between negotiating parties, the Act will not result in greater power for employees to determine their employment conditions. Finally, while the Act's supporters praise the Act as a means of fostering communication and co-operation between employers and employees, opponents point to the emergence of a "conflict model" of industrial relations (Foulkes, 1992: 12). Thus, a fourth proposition tests whether the Act will lead to improved communication and cooperation between employees and employers.

\section{Health sector reform in New Zealand}

In 1983, the Area Health Boards Act devolved public health activities previously carried out by the Department of Health to the regions, marking the beginning of the "rationalisation and regionalisation" of health funding and provision (Ashton, 1992: 149). 
Under this Act, a "global cap" was put on hospital budgets through the introduction of a population-based funding formula for allocating resources to the public hospitals, and from 1988 on, individual health boards were required to negotiate budgets and performance criteria with the Government. These initiatives were expected to improve efficiency of resource use within the boards, who were operating with decreasing levels of government funding.

Perhaps the most significant change to New Zealand's public health sector has been the shift from a traditional public sector administrative function towards a management orientation. The rise of managerialism within the health sector has led to tension between private sector management practices and a prevailing culture based on the provision of quality patient care. In turn, a new culture centred around cost-cutting and the quantification of performance and output has emerged, provoking opposition from health sector employees. Summing up the situation in New Zealand's public health sector, Easton (1992: 28) stated "all around the country there is a very deep-seated distrust of management". As a result, a number of commentators have argued that the health sector reforms of the last decade have led to a working environment in the public health sector in which low employee morale, high stress and dissatisfaction prevail (see Campbell, 1988, 1992; Coddington, 1990).

\section{Health sector collective bargaining}

Prior to the Act's final passage in May 1991, most of the state sector awards and agreements were rolled over, remaining in force until 30 June 1992. Consequently, the bargaining round begun on the 1st of July 1992 was the first full public sector bargaining round to be conducted under the Employment Contracts Act.

In late March 1992, the Ministers of Health and State Services met with area health board general managers. Stressing the tight fiscal environment for the round, their directives to managers centred on the negotiation of separate collective employment contracts in each of the 14 area health boards, greater flexibility in working hours, and modifications to penal rates (Luke, 1992). The Ministers' directives reflected the Government's desire to introduce bargaining reforms in the public sector which would parallel private sector reforms, particularly the decentralisation of bargaining from national to enterprise or individual documents and the reductions in penal rates. The use of the Employment Contracts Act to achieve these outcomes was favoured because the Government, as paymaster of 58,000 area health board workers, desired a reduction in State labour costs (Luke, 1992). A \$2.7 billion deficit was claimed as making reductions in state sector spending imperative. These directives met with a hostile reaction from health sector unions, who accused the Minister of "declaring war" on their members (Roth, 1992). The stage was set for what was potentially a major confrontation. 


\section{The negotiations - a summary}

On the first day of the CAHB negotiations, the employers tabled their claim and engaged in an opening address outlining the "unique set of circumstances" under which they were bargaining. Future health reforms, decreased funding, the Employment Contracts Act, and the flexibility achieved by private sector employers in the area of penal rates were all referred to. Consequently, the CAHB's claim sought to achieve flexibility through reductions in penal and overtime payments and changes to working hours. In contrast, the NZNA claim retained current conditions of employment and sought a three percent wage rise. Additionally, the NZNA outlined a key element of its claim - the notion of workplace reform - as an alternative strategy to cost-cutting. The union advocate asserted that workplace reform would lead to improved service quality through the revision of work practices. Initially, the Board rejected the proposal, later accepting the notion and jointly formulating a memorandum of understanding with the NZNA which outlined both parties' commitment to the concept.

After four days of negotiations, joint stopwork meetings were held. Negotiations had reached a deadlock, and both parties wished to address the nursing staff to outline their respective positions. After presenting their claims, the two parties gave an overview of the negotiation process to date. Nurses expressed extreme anger towards management and members unanimously rejected the Board's proposed wage cuts. Talks resumed on day five with the NZNA stating that the anger displayed by members at the stopwork meetings served to reinforce their original strategy. However, the CAHB responded with a package which involved greater pay cuts than packages previously offered. In turn, the NZNA developed a package in which lump-sum "shift allowances" replaced penal rates, similar to packages developed by NZNA regional representatives during negotiations with neighbouring area health boards. In response, the CAHB offered a settlement which substantially lowered NZNA's proposed shift allowances.

Day six of negotiations followed the same course. Each side calculated and recalculated base rates and shift allowances (with increases in the base rate resulting in reduced shift allowances) in order to arrive at a package that the other party would find satisfactory. The NZNA formulated settlements that were close to "cost-neutral" (where the nursing budget was retained at its present level), while the CAHB tabled settlements proposing reductions in the nursing budget. The CAHB announced that they would not accept a cost-neutral settlement, and a mutual adjournment was agreed upon. On day eight the NZNA presented the CAHB with a roll-over of the expired award, giving away only one concession. Surprisingly, the CAHB responded positively, offering a package which the NZNA considered "more attractive" than any package offered yet. Both sides gradually started moving towards a settlement and offers back and forth resulted in agreement, with the employers meeting all union claims apart from slight reductions in penal rates. The parties arrived at a settlement they believed would be ratified, and stopwork meetings were held in order for members to ratify the contract. To both parties' surprise, the ballot showed overwhelming evidence of members' dissatisfaction with the offer; of 1,400 nurses who voted, 1,100 rejected the proposed settlement.

Following the breakdown in negotiations, nurses were balloted on their intention to strike. 
The ballot resulted in 80 to 90 percent of all nurses voting in favour of strike action. Combined strikes were planned for five days in total, in which 5,500 employees from three area health boards were to take industrial action simultaneously. Following the lead of the Taranaki Area Health Board, on the day before the first scheduled strike the Canterbury Area Health board applied for an interim injunction against the NZNA. The injunction was filed on the grounds that the association had not complied with section 69 (4) of the ECA and given proper strike notice, and its strike ballot had been misleading. However, the injunction failed and nurses took strike action over two of the five days of proposed strikes.

Three sets of informal talks were held by the parties on the days prior to and following strike action. The first two days of talks failed to reach agreement, while the third day was more productive and led to discussion of the issues to be resolved in the final two days of negotiation. Prior to final negotiations the NZNA developed a proposal in which penal rates were reformulated as shift allowances and were calculated as an hourly rate in addition to ordinary time based on a nurse's grading. These hourly rates differed from the shift allowances originally proposed by the NZNA, which were lump sum payments which varied by shift. They also differed from the previous system of penal rates, as they were not proportionately related to the basic hourly rate in the way that penal rates were. The proposal met with the CAHB's acceptance, and negotiations proceeded from this point. Consequently, the final two days of negotiations followed the same sequence as those negotiations prior to the breakdown, in which both teams calculated and recalculated financial data in order to arrive at a mutually satisfactory package.

The final settlement maintained the nursing budget at its current level (a cost-neutral settlement) with all monetary changes in penal rates channelled into a base rate increase of 1.8 percent. During final negotiations the board had modified its demands significantly, moving away from a position of seeking a $\$ 3.4$ million saving, to being prepared to settle a cost-neutral agreement. The industrial relations manager explained that this turnaround was because the negotiation period "was taking too long", and because "the prospect of further strikes was not favourable". The settlement was fully ratified by members at stopwork meetings and the two parties began drafting the employment contract.

\section{Discussion}

The negotiation process was analysed in light of the propositions outlined earlier, and the findings structured according to these four propositions. Thus, the first section examines the extent to which bargaining processes have changed under the ECA, while the second examines whether the CAHB used the Act to lower wages and exclude unions from the employment relationship. The third section investigates whether nurses' power to determine their employment conditions has been enhanced by the legislation, while the fourth tests the proposition that the Act led to improved communication and co-operation between CAHB management and nursing staff. 


\section{The bargaining process}

Commentators have noted that the ECA significantly changes the bargaining process, which traditionally in New Zealand has involved the centralised negotiation of awards and agreements which were then extended to the whole industry. The study highlights changes in three areas that impact on the bargaining process - ratification procedures, decentralised bargaining, and the composition of bargaining teams.

The Act's requirement for the establishment of ratification procedures effectively enables individual workers to influence bargaining outcomes. However, although democratic in substance, the ratification process served as a major hazard to NZNA negotiators. Team members were constantly unsure of how employees would react to proposed settlements or proposals for industrial action. This lent an air of uncertainty to the process and resulted in negotiations proceeding slowly, as the NZNA team considered and made allowances for every possible outcome. The membership's rejection of a deal which the negotiating team considered palatable demonstrated the potential for the negotiation process to be lengthened due to members' non-ratification of agreements.

Decentralised bargaining at the regional level meant that the Canterbury negotiations were setting the pace for a number of other negotiations. Similarly, the outcomes of the Canterbury negotiations depended on the results of concurrent regional negotiations being conducted throughout the country. On more than one occasion, both parties' bargaining strategies were revised in light of negotiation outcomes in other regions. The NZNA advocate for the Canterbury negotiations was also the advocate for the Nelson-Marlborough negotiations, and at one point during negotiations he proposed similar packages (which replaced penal rates with shift allowances, effectively lowering conditions) in both regions. The NZNA team became concerned that the package would be ratified in Nelson, thus encouraging the CAHB to offer the same contract to CAHB nurses. However, once Nelson nurses rejected the package, NZNA's position was strengthened. Such a rejection indicated to the CAHB that workers would not accept wage cuts and made it clear to the board where the limits of a possible settlement were. It is interesting to note, however, the board's enthusiasm for adopting contracts proposed in other regions. At one stage, when it appeared ratification of the proposed Nelson settlement was imminent, the CAHB's advocate aligned himself with the Nelson-Marlborough Area Health Board and was insistent that an almost identical document be settled by the Canterbury negotiators. In response, the NZNA advocate highlighted the apparent contradiction in the board's bargaining strategy. He noted that whereas during initial negotiations the CAHB had wholeheartedly endorsed bargaining on a region-by-region basis, it was now advocating that a neighbouring board's document be adopted for use within its own region. Thus, the employer in this study was somewhat reliant on "relativities" between regional bargaining outcomes when it was perceived to be to advantage. This contrasts directly with criticisms of the "inflexible" nature of the previous industrial relations framework, based on what Birch described as "a rigid system of relativities" (Birch, 1991: 2).

The composition of the bargaining team also resulted in changes to bargaining procedures. Decentralised bargaining led to direct employee representation in negotiations, as the bargaining team was composed of delegates from a cross-section of regional hospitals. Team members were representative of all levels of the nursing hierarchy from hospital aides 
to charge nurses. However, whereas in award negotiations NZNA bargaining teams were composed of union officials with experience in negotiations, regional bargaining resulted in the involvement of teams of delegates who had little negotiating experience. Both the union advocate and CAHB's industrial relations manager believed that this resulted in negotiations proceeding more slowly than in the past. However, the union advocate believed that delegate representation on the team was essential, as the delegates provided feedback at all stages of the process by gauging workplace opinion on proposed settlements and bargaining options. Delegates surveyed the workforce to assess the outcomes of ratification ballots, and measured the effects of the Board's proposals on the "average nurse" by calculating the impact of proposals on their pay packets.

Thus, it was found that the Employment Contracts Act has resulted in significant changes in the collective bargaining process. The Act's emphasis on the decentralisation of bargaining to the enterprise, or in this case, regional level, was evident in the present study. In addition, new ratification procedure requirements and the composition of the union bargaining team resulted in the negotiation process proceeding more slowly, and in a more uncertain manner, than previously.

\section{Use of the Act to achieve its implicit aims}

This study found that although to some extent the employer party was able to achieve those aims highlighted by the Act's critics (reductions in wage costs - particularly penal rates and the exclusion of unions from the employment relationship), the final settlement was highly favourable for employees and the NZNA. Although the employer sought to exclude the NZNA as a party to the contract and reduce nurses' wages, it had little success in achieving either aim.

The central focus of the negotiation process was the restructuring of payment systems to match similar reforms in the private sector. Consequently, throughout negotiations the CAHB frequently compared the public health sector with private sector industries, in order to justify the proposed wage cuts central to their claim. board management repeatedly emphasised the "social change" taking place throughout New Zealand, maintaining that New Zealand was becoming a "Monday to Sunday society". The board's argument in favour of reducing penal rates was based on comparisons between the health sector and the retail sector. The board's advocate likened hospital operations to those of retail outlets. $\mathrm{He}$ argued that nurses were not exempt from changes taking place in other sectors of the economy, in particular the shift towards greater wage flexibility and changes to working hours, and asserted that such sentiments were widespread public opinion. The NZNA refuted the board's comparison between the health and retail sectors, highlighting the crucial differences between them. The union advocate argued that there was little basis for comparison, owing to the fact that customers for health services differ markedly from customers for consumer goods, and that hospitals are highly dissimilar to retail outlets as they operate 24 hours a day, 365 days a year. The union advocate observed that it was the employer's freedom to negotiate penal rates downward that was the significant issue. Consequently, the board's proposal to reduce penal rates quickly became a sticking point in negotiations. By the conclusion of negotiations, the shift allowances eventually agreed upon were almost equivalent to the penal rates set out in the former award, and 
consequently few nurses experienced wage losses. However, these modifications to the payment structure fulfilled the Minister of State Services' directives, retaining penal rates by recalculating and renaming them. It is interesting to note that it was the union party who actively developed the new wage structure which finally met with the board's agreement. It seems that the union realised that if negotiations were to proceed further, the one barrier to be broken down was the Government's "ideological opposition" (Macfie, 1992: 24) to penal rates.

The CAHB's bargaining strategy centred around lowering penal rates and increasing base rates. Such a strategy provides management with the opportunity to create divisions between workers who work primarily penal hours and those who work ordinary hours by encouraging those who work weekday (nine to five) shifts to sign contracts containing high base rate increases. This results in a situation where such workers lose sight of the gains to be made from a unified stance and consequently, collective strength is reduced. NZNA bulletins to members stated:

NZNA supports Monday to Friday workers and their need for an increase in the base rate. However this increase cannot come from fellow workers as a decrease in their wages is unacceptable to them. NZNA will continue to fight for more money for all nurses. (NZNA Pay Negotiations, Bulletin 10)

The union team avoided confronting the difficult issue of whether the existing wage structure was fair, instead justifying the higher wages paid to weekend and night workers by constant references to the "unsociable hours" worked by these employees, and demanding wage increases for all nurses.

During negotiations the composition of the NZNA bargaining team led to the emergence of a division between delegates who worked weekend/night shifts, and those who were Monday to Friday workers. Whereas the advocate and the delegates who worked ordinary hours saw strike action as a "last resort", the weekend workers repeatedly advocated strike action. Throughout the negotiations, these team members constantly reminded the group of the central focus of the NZNA's bargaining strategy; that members had mandated that they would not take a cut in wages. It became evident that the delegates who were weekend/night workers had significantly more at stake than the other team members and were anxious to preserve their current wages and conditions. Team members wished to ensure that neither group of NZNA members was disadvantaged by the final settlement, yet each had a vested interest in ensuring that there would be no reduction in their individual incomes. Thus, it became increasingly hard for negotiators to bargain for the status quo as "dollars and cents" issues began to dominate negotiations. The composition of nurses' pay packets (the proportion of penal hours and normal hours worked) varied widely, and consequently negotiators found it difficult to estimate the effects of proposals on individual nurses' pay packets to any degree of precision. The union team requested that the CAHB provide them with financial information including projections of wage costs, breakdowns of total wage expenditure (into penal rates and ordinary hours), and information on the proportions of workers working ordinary and penal hours. However the CAHB was reluctant to divulge such information. Consequently, union negotiators were unable to assess the validity of "ability to pay" arguments put forward by the board, and were also hampered in their efforts to develop a proposal which would not unfairly advantage one group of workers over another. 
The Act's opponents maintain that the legislation leads to a short-term cost-cutting focus among employers, who fail to recognise the benefits of investing in long-term initiatives such as skills development, workplace design and work methods reform, all of which were included in the NZNA's proposal for workplace reform. The board's initial rejection of the proposal, and its reluctance to accept that the concept was relevant to contract negotiations, validates such criticisms of the Act. The CAHB stated that long-term initiatives "... were not part of these negotiations ... our emphasis is on the short term ... issues relating to consultation with employees are outside this document". This statement undermines supporters' assertions that the Act would provide a vehicle for improving communication and co-operation between employees and employers, and a means by which a wider range of workplace issues could be addressed during the contract negotiation process. The Act's implicit aim of reducing wage costs featured prominently in the board's bargaining strategy, while longer-term initiatives were excluded from negotiations.

The CAHB sought to weaken union influence in the workplace by attempting to exclude the NZNA as a party to the contract and from the memorandum of understanding verifying the CAHB's acceptance of the concept of workplace reform. The CAHB argued that the union was the employees' bargaining agent, (implying a short-term relationship between the employee and union), while the NZNA argued that it was in fact the employees' representative, emphasising NZNA involvement in a wide range of professional and industrial areas. It is interesting to note that although the term is used frequently by employers and others, the ECA makes no mention of bargaining agents, and refers only to representatives. Furthermore, the CAHB argued that "employers and employees may want to consult with each other and no other third party" implying that union representation would impede communication between the primary parties to the contract. In response, the union advocate emphasised the benefits to the employer of negotiating with an organisation such as the NZNA, noting that the alternative was 2,500 individual negotiations with workers, or engaging in contract negotiations with a multiplicity of bargaining agents.

In this study, the employer sought to negotiate wage cuts through the removal of penal rates, in line with similar trends in the private sector. However, although the employer was initially insistent that it had to make a four to five percent saving, stating that "the alternative is jobs", the final settlement maintained the nursing budget. Consequently, the employer was unable to use the ECA to achieve the implicit aim of lowering wages. Similarly, while the board sought to exclude unions from the employment relationship by trying to exclude them from the workplace reform programme and as a party to the contract, the union gained inclusion in both documents, thus formalising its role as employee representative.

\section{Employee power to determine employment conditions}

The contract negotiations between the two parties resulted in a favourable outcome for the employees and their representatives. Initially, the board assumed an aggressive bargaining stance, threatening substantial reductions in the nursing budget. At the conclusion of negotiations, the employees had all but maintained their present income level, contrary to their prior expectations. A number of fortuitous circumstances combined to result in the favourable settlement that was reached. These included the time constraints the board faced 
in negotiating the contract (as CAHB negotiators were bargaining with multiple occupational groups simultaneously), effective strike action, the high degree of unity among the region's nurses (and hence the decreased likelihood of fragmented bargaining arrangements emerging), and the fact that the employers' represenatives, in the opinion of the NZNA advocate, "were not as aggressive as they could have been". It was acknowledged by both parties that nurses were a powerful occupational group in terms of both the group's size, and the level of public sympathy they engendered.

Employee power to determine employment conditions was enhanced by the Act's ratification procedures, which provided individual workers with the opportunity to determine bargaining outcomes. The ratification process enabled employees to calculate the effects of proposals on their wages and vote accordingly. Employees' rejection of a package that had met with the approval of both negotiating teams showed that the ratification process had the potential to result in a situation whereby employee power to dictate the course and outcomes of negotiations overrode that of the union negotiators. However, in some instances ratification procedures can lead to unsatisfactory outcomes for certain employees in minority groups. As a result of the ratification of a proposed settlement by the majority of employees during 1992 contract negotiations between the NZNA and the Otago/Southland Area Health board some nurses received pay cuts of up to $\$ 10,000$ per year. Many nurses in the region were extremely dissatisfied with this outcome. Consequently, the nature of the ratification process means that union members who constitute a "minority" within a larger group of workers will often find their power to determine their employment conditions reduced. Moreover, although the ratification process afforded employees greater power to determine their working conditions, it also placed restrictions on their representatives (as outlined earlier).

Decentralised bargaining led to variations in employee power between regions, as nurses in some regions were more willing to strike and were more unified than those in others. The ECA provides employers with the opportunity to use a "divide and rule" strategy, thus reducing employee power by fragmenting the workforce. Employers may encourage a climate of self-interest among workers by offering one group of employees a contract that they consider attractive, but which reduces the conditions of another group (or by approaching workers directly without the knowledge of their bargaining representative), resulting in a divided workforce. However, unity among nurses in the Canterbury region prevented CAHB management from pursuing such outcomes. Furthermore, the Employment Court's rejection of the board's application for an interim injunction to prevent strike action marked an important turning point in negotiations. The granting of the right for nurses to strike and the subsequent strike action itself signalled a swing in bargaining power towards the employees and their representatives. Successful strike action provided tangible evidence of the strength of unity between the region's nurses. The NZNA advocate stated that in terms of bargaining power and resolve to strike, nurses in Canterbury were a lot stronger than nurses nationwide.

However, certain groups of workers were rendered powerless in determining their own employment conditions. During the course of negotiations the CAHB began employing new employees on individual employment contracts containing significantly less favourable wages and conditions than those of the existing workforce. In addition, casual nursing staff were issued with new employment contracts containing substantially reduced wages and 
conditions, and were told by management that if they did not sign the contracts by a certain date they would be given no further work. The wages and conditions in both sets of contracts were based on the board's claim. The actions of CAHB management served to hasten the bargaining process somewhat, as the bargaining team were aware of the vulnerability of both groups of workers. These workers were highly reliant on a settlement by the negotiating parties in order to restore their wages and conditions to their previous level in the case of casual workers, and to bring about parity between the wages of new employees and existing staff. Hence, the union was aware of the fact that the longer it took to settle the contract, the longer these workers would be working under inferior conditions. Although casual and new employees were eventually brought under the new contract settled, they were essentially powerless to determine their own conditions of work during the negotiation process.

This study found that in some respects, employee power to determine employment conditions has increased, true to the rhetoric surrounding the Act's introduction. The Act's ratification procedures enabled individual workers to determine bargaining outcomes through majority vote, and the high level of unity among the nurses increased their collective power to dictate the course of negotiations. However, certain groups of workers who constitute a minority of the total nursing workforce may find that the ratification process actually obstructs them from influencing negotiation outcomes. In addition, the study found that vulnerable groups of workers such as casual and new employees were unable to determine employment conditions during the negotiation process.

\section{Employee-employer communication and co-operation}

Contrary to the predictions of the Act's supporters, this study found that communication and co-operation between employees and the employer deteriorated during negotiations. This finding verified the proposition that the Act would not lead to increased communication and co-operation between the two parties. Meanwhile, high levels of communication and cooperation between the NZNA and its members were apparent, as evidenced by high levels of member involvement and participation in the formation of the bargaining strategy, stopwork meetings and strikes, and support for the negotiating team.

While morale was low among the nursing workforce prior to the contract negotiations, employer-employee relations deteriorated further during the bargaining process. The negotiation process and in particular the stopwork meetings and strike, served to intensify and consolidate nurses' anger and provide a direction for its outlet. Stopwork meetings in particular provided ample evidence of nurses' anger towards CAHB management. The meetings provided a means by which nurses were able to vent their anger and frustration, and it seemed that the nursing staff considered them a vital means of communicating such feelings to management. Managers were heckled and booed loudly while addressing staff, and individual nurses challenged management on its position and outlined how much they stood to lose under the board's proposed cuts. Employees highlighted the inequity in compensation between managers and nurses, criticising manageis for imposing wage cuts upon medical staff while being exempt from wage cuts themselves. Thus, during negotiations employer-employee relations worsened, as the stopwork meetings fuelled the nurses' anger and strengthened their resolve. Proponents of the Act advocate that direct 
communication between employees and employers (previously hindered by the intervention of unions) serves to strengthen the relationship between the primary parties to the employment contract. However, this study shows that in some instances direct communication may in fact aggravate tensions between employees and employers.

As with the stopwork meetings, it became evident that the strike also served as a vehicle for the expression of nurses' anger. Ostensibly, workers were striking over the preservation of their employment conditions. However, it became clear from interviews with union organisers and NZNA team members, and officials' and members' statements to the press, that they were also striking over the health reforms of recent years and all that they have entailed: conflict between management and health professionals, the axing of essential services, the lack of consultation with nursing staff, and the subsequent detrimental effects on patient care. Indeed, the union advocate stated that nurses' anger was such that nurses in a nearby region would have taken strike action "even if they had got a rollover". The strike served as a means of venting anger and displaying unity, while enabling the union to assert its bargaining power.

The NZNA team members communicated nurses' dissatisfaction to management and to the central union office. While award negotiations had excluded the direct input of nurses at a regional level, the present negotiations enabled workplace representatives to express their anger and frustration. In defense of penal rates, the delegates forcefully conveyed to the CAHB team the dysfunctional consequences of working penal hours. One delegate stated, "Your health suffers when you work nights. You don't get to see your family. I'm unwell because I've worked the last seven afternoon duties" (3pm to $11 \mathrm{pm}$ ). To which a fellow delegate added "This is what nurses are saying and it is fundamental to them". The decentralisation of bargaining improved the opportunities for employees to directly communicate with management, although it did not appear to improve co-operation between the parties.

Improved employer-employee communication may result if workplace reform is implemented within CAHB hospitals. However, the Act sets up constraints on implementing any such reforms due to health sector contract negotiations proceeding on a yearly basis, in line with the "hard budgets" set by management. The Act requires negotiating parties to expend substantial time and financial resources on preparing for yearly contract negotiations, resources that might otherwise be invested in developing initiatives such as workplace reform. Moreover, although CAHB management recognised the need for a mechanism to improve communication between management and employees, such a mechanism was not initiated by management, but by the union. Thus, contrary to the assertions of the Act's supporters that the new legislation will result in improved communication and co-operation between employees and employers, the relationship deteriorated over the negotiation period, to the point where nurses engaged in industrial action. However, as mentioned previously, nurses took industrial action due to a combination of factors, and consequently it is not possible to conclude that industrial action was taken solely on the basis of dissatisfaction with changes brought about by the Employment Contracts Act.

While the relationship between the CAHB and its employees deteriorated over the course of negotiations, it became apparent that the relationship between the union and its members 
was strengthened. The NZNA made substantial efforts to aid communication between the union national office and members, and to promote unity among members. The union sought membership involvement at every stage of the negotiation process, including during the development of its bargaining strategy and claim, and provided members with information on negotiations as they progressed through bulletins and meetings conducted by delegates in the workplace. Members were able to influence the bargaining position of the union by communicating their views to team members during these meetings. Moreover, from early in the pre-negotiation preparation phase, NZNA set about informing workers of their rights under the Act. The contract negotiations and the strike united members and led them to identify more closely with the NZNA. However, the strengthening of the employee-union relationship in the Canterbury negotiations can be contrasted with the fragmentation and dissension among NZNA members in other regions, where groups of workers formed splinter groups and negotiated contracts directly with employers.

The new industrial relations environment could be viewed as constituting "uncharted territory" for public sector unions such as the NZNA who had not yet experienced a bargaining round under the Act. However, NZNA prepared themselves for the hurdles created by the Act well in advance of the negotiations by seeking extensive legal advice on the ratification process, balloting procedures, notice of strike action, and defence of the interim injunction. Boxall \& Haynes (1992) found that those unions whose workplace organisation efforts are effective, who allocate resources to delegate training and involve themselves in enterprise issues beyond the traditional concerns of collective bargaining have been less affected by the Employment Contracts Act to date. The NZNA fits this model. High levels of on-site organisation (aided by the organisational structure of hospitals), highly-trained and committed delegates, and the involvement of the union in professional issues has resulted in a unified, powerful and well-informed membership, which in turn has contributed to union success in negotiations.

In direct contrast to predictions that the Act would lead to a closer relationship between employers and employees, in this study employee-employer relations worsened over the course of negotiations, with stopwork meetings exacerbating nurses' anger. It became apparent that increasing levels of conflict between employer and employees led nurses to identify more closely with the union, which offered protection against lowered conditions of employment.

\section{Conclusion}

The purpose of this study was to document and analyse the process of collective bargaining in the Canterbury Area Health board under the Employment Contracts Act (1991). The study focused on a controversial sector, one in which social policy issues and industrial relations issues were intertwined, making for a highly volatile negotiation period.

It can be concluded that in this case bargaining procedures have changed to a major extent under the Act. This is due to a combination of factors including ratification procedures, 
decentralised bargaining structures, and bargaining team compositions. Employee power to determine employment conditions was enhanced for the majority of workers due to employee input in the ratification of contracts and bargaining teams, while certain minority groups of workers were unable to influence employment conditions. It was found that the Act does not foster communication and co-operation between employees and employers; rather, the opposite is more likely to occur. Consequently, low levels of communication and co-operation between employees and employers united union members, and strengthened the employee-union relationship. In terms of the employer's use of the Act to achieve its implicit aims, ideological opposition to the notion of penal rates led to the development of a changed payment structure.

When asked to predict how trade unions would respond to the new industrial relations environment resulting from the ECA, Douglas (1991: 18) answered "Unevenly, in an evolutionary manner, on the basis of conflict and relative strength and in a changing way as events and experiences unfold". In the present study both parties had no alternative but to proceed in an evolutionary manner, as their course through the bargaining process was marked with hurdles and pitfalls set up by the new legislation. The parties learned by experience as they progressed through the negotiation process, in a similar manner to the bargaining parties in Walsh \& Fougere's study of the first round of health sector bargaining under the State Sector Act (1988). In their study, Walsh \& Fougere (1989: 220) note that although the State Sector Act was conceived as an empowering agent for management... in other unexpected and unintended ways it also empowered unions and hobbled management". A strikingly similar outcome was evident in this case study, as the union was empowered by certain provisions in the new legislation and by its members' cohesiveness. This study chronicles the impact of a changed institutional environment on the interactions between participants involved in the process of negotiating a collective employment contract. It is hoped that this case study of bargaining under the Employment Contracts Act, essentially exploratory in character, lays a foundation for future case studies of contract negotiations in the health sector and in other sectors.

\section{References}

Ashton, T. (1992), Reform of the health services: Weighing up the costs and benefits, in Boston, J. and Dalziel, P. (eds.), The Decent Society? Essays in Response to National's Economic and Social Policies, Auckland, Oxford University Press.

Birch, W. (1991), Address to the Longman Professional Conference, Pan Pacific Hotel, Auckland, May 71991.

Boxall, P. \& Haynes, P. (1992), Unions and non-union bargaining agents under the Employment Contracts Act 1991: an assessment after 12 months, New Zealand Journal of Industrial Relations, 17(2): 223-232.

Bradford, M. (1991), The scope for change offered by the Employment Contracts Act, The Press, May 14 1991: 17. 
Brook, P. (1991), The Employment Contracts Act: Two steps forward, one step back, Public Sector, 14(2): 8-9.

Campbell, G. (1988), The Nurses' revolt, New Zealand Listener, March 26, 1988: 16-18.

Campbell, G. (1992), Hospital Horrors, New Zealand Listener, October 17, 1992: 28-34.

Coddington, D. (1990), Wellington's Hospital Woes, North \& South, September 1990: 105-117.

Department of Labour (1993), A Survey of Labour Market Adjustment under the Employment Contracts Act 1991 (November 1993)

Douglas, K. (1991), The Employment Contracts Bill, The Examiner, April 18 1991: 18. Easton, B. (1992), An alternative health system, National Business Review, May 5 1992:
28.

Employment Contracts Act (1991), Government Print.

Foulkes, A. (1992), The Impact of the Employment Contracts Act on the Trade Union Movement, Public Sector 15(2)11-12

Gosche, M. (1992), The Impact of the Employment Contracts Act 1991: Reviewing the Act: Unions and Bargaining Agents, Paper presented to the Employment Contracts Act: One Year On Seminar, Industrial Relations Centre, Victoria University of Wellington, May 15
1992.

Hammond, S. (1994) Equity and Enterprise Bargaining: Lessons from the Experiment, Paper presented to the 8th AIRAANZ Conference, Sydney, February 121994.

Harbridge, R. (1993), Collective employment contracts: a content analysis, in Harbridge (ed), Employment Contracts: New Zealand Experiences, Victoria University Press,
Wellington.

Hill, L. and Du Plessis, R. (1993), Tracing the Similarities, Identifying the Differences: Women and the Employment Contracts Act, New Zealand Journal of Industrial Relations,
18(1): Hughes, J. (1992), What Bill Birch should do to repair flaw in Act, The Press, June 9 1992:
12.

Luke, P. (1992), Govt to confront unions over huge wages bill, The Press, April 4 1992:
10. 
Macfie, R. (1992), Nurses on front foot: "What about the workers?", National Business Review, October 2 1992: 24.

Marshall, S. (1992), Employment Contracts Act: Changes in the State Sector - A Comparison with the Private Sector, Public Sector 15(2): 7-8.

National Distribution Union (1992), Under Contract: A Brief Report on the Use of the Employment Contracts Act in the Retail Sector.

New Zealand Nurses Association (1992), Pay Negotiations Bulletins (Canterbury Region) (1-15) $22 / 5 / 1992-14 / 10 / 1992$.

New Zealand Nurses Organisation (1993), Myths and Reality: The Effect of the Employment Contracts Act on Nurses in New Zealand (1991-1993), Paper presented to the ICN Congress, June 1993, Madrid.

Press, "Communications improved" by Contracts Act, December 17 1992: 3.

Roth, H. (1992), Chronicle, New Zealand Journal of Industrial Relations, 17(2): 247-258.

Scott, J. (1991), Employment Contracts Act - An Overview, Public Sector, 14(2): 2-5

Walsh, P., and Fougere, G. (1989), Fiscal policy, public sector management and the 1989 health sector strike, New Zealand Journal of Industrial Relations, 14(3): 219-229. 


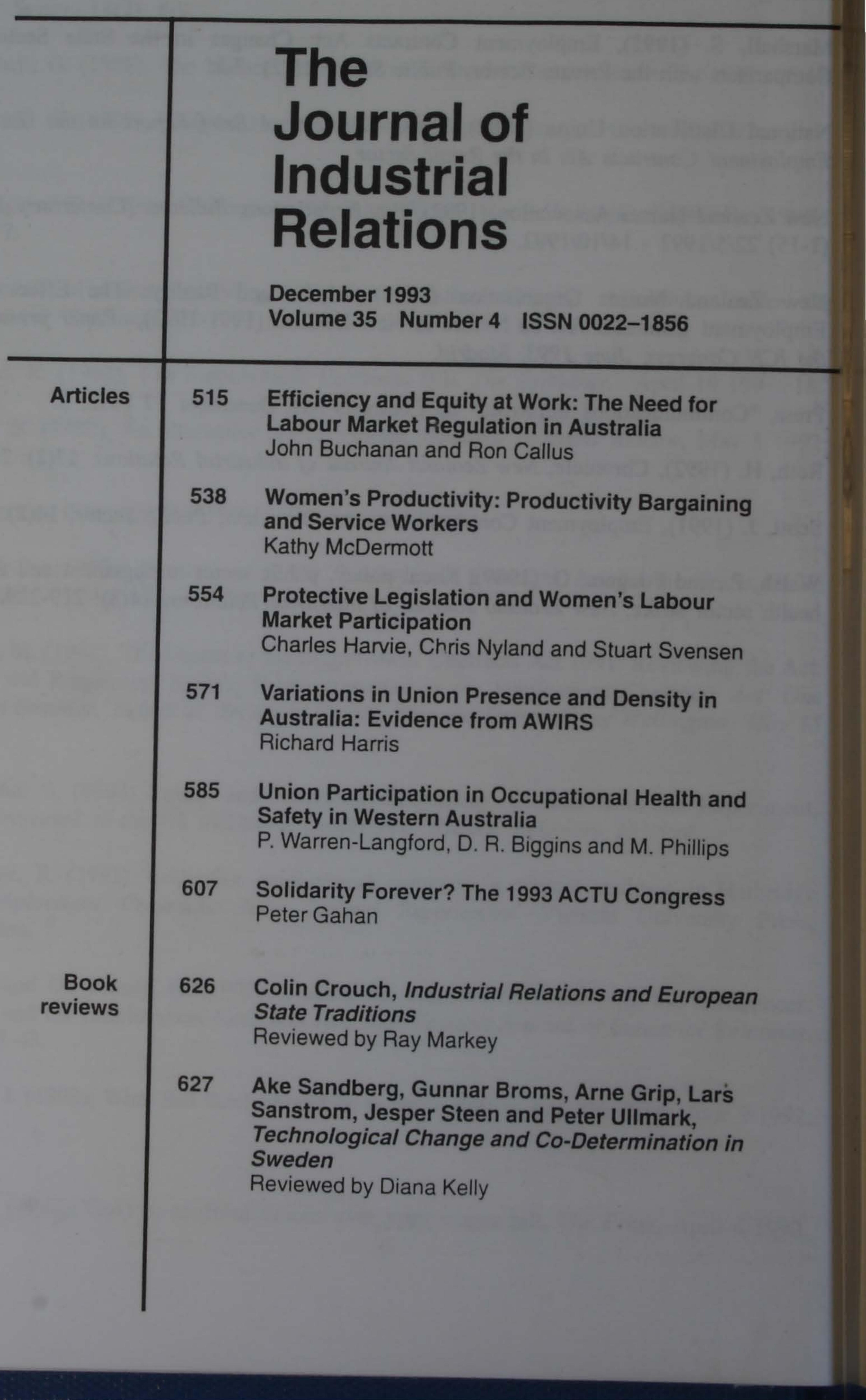

